\title{
Task 20 - Prevention of Chloride Corrosion in High- Temperature Waste Treatment Systems (Corrosives Removal From Vitrification Slurries)
}

\author{
Semi-Annual Report \\ April 1 - September 30, 1998 \\ By \\ TFCEIVED \\ MAR 081999 \\ OSTI \\ Ted R. Aulich; Ronald C. Timpe
}

Work Performed Under Contract No.: DE-FC21-94MC31388

For
U.S. Department of Energy
Office of Fossil Energy
Federal Energy Technology Center
P.O. Box 880
Morgantown, West Virginia 26507-0880

By

Energy \& Environmental Research Center

University of North Dakota

P. O. Box 9018

Grand Forks, North Dakota 58202-9018 


\section{Disclaimer}

This report was prepared as an account of work sponsored by an agency of the United States Government. Neither the United States Government nor any agency thereof, nor any of their employees, makes any warranty, express or implied, or assumes any legal liability or responsibility for the accuracy, completeness, or usefulness of any information, apparatus, product, or process disclosed, or represents that its use would not infringe privately owed rights. Reference herein to any specific commercial product, process, or service by trade name, trademark, manufacturer, or otherwise does not necessarily constitute or imply its endorsement, recommendation, or favoring by the United States Government or any agency thereof. The views and opinions of authors expressed herein do not necessarily state or reflect those of the United States Government or any agency thereof. 


\section{DISCLAIMER}

Portions of this document may be illegible in electronic image products. Images are produced from the best available original document. 


\section{TABLE OF CONTENTS}

LIST OF FIGURES $\ldots \ldots \ldots \ldots \ldots \ldots \ldots \ldots \ldots \ldots \ldots \ldots \ldots \ldots \ldots \ldots \ldots \ldots \ldots$

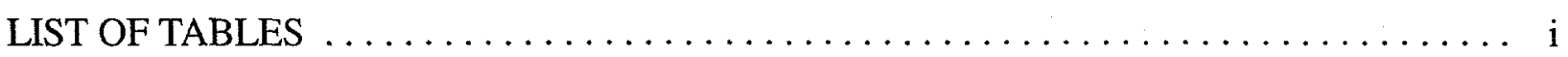

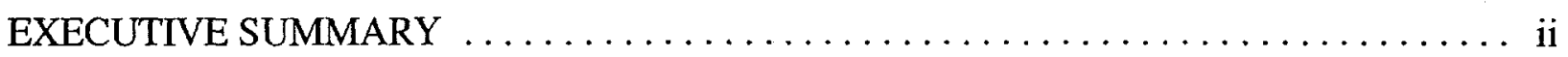

INTRODUCTION/BACKGROUND $\ldots \ldots \ldots \ldots \ldots \ldots \ldots \ldots \ldots \ldots \ldots \ldots \ldots$

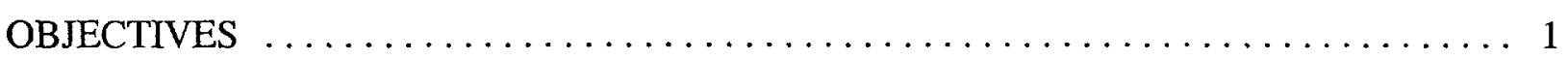

ACCOMPLISHMENTS $\ldots \ldots \ldots \ldots \ldots \ldots \ldots \ldots \ldots \ldots \ldots \ldots \ldots \ldots \ldots \ldots \ldots \ldots$

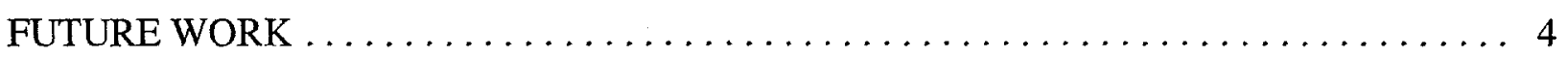

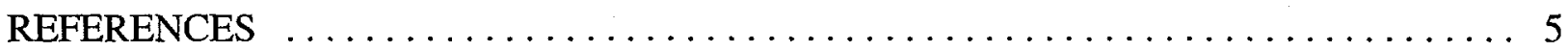

\section{LIST OF FIGURES}

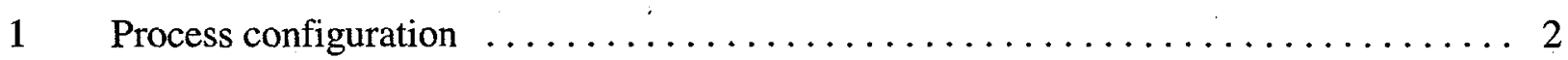

2. Membrane separation test apparatus $\ldots \ldots \ldots \ldots \ldots \ldots \ldots \ldots \ldots \ldots \ldots$

\section{LIST OF TABLES}

1 Ion-Specific Membrane Separation - 5-Molar NaOH Solution Diffusion Only - No Electrolysis Voltage $\ldots \ldots \ldots \ldots \ldots \ldots \ldots \ldots \ldots \ldots$

2 Ion Exchange via Metal-Intercalated Cation Exchange Resin - 5-Molar NaOH Solution Trickle-Bed Treatment . . . . . . . . . . . . . . . . . . . . . . . . . 4 


\section{EM TASK 20 - PREVENTION OF CHLORIDE CORROSION IN HIGH- TEMPERATURE WASTE TREATMENT SYSTEMS (Corrosives Removal From Vitrification Slurries)}

\section{EXECUTIVE SUMMARY}

With assistance from GTS Duratek of Columbia, Maryland, the Energy \& Environmental Research Center (EERC) in Grand Forks, North Dakota, has developed a three-step process to remove corrosives (primarily chloride and sulfate) from low-level radioactive, hazardous, and mixed wastes destined for vitrification. The EERC is optimizing the process for incorporation into a commercial system for remediation of tank wastes at the Hanford site in southeast Washington. Sulfate in vitrification feedstocks is undesirable because it can damage the vitrifier electrode, and chloride is undesirable because it can damage components of the vitrifier emission control system. Removal of corrosives from tank wastes is difficult because the presence of up to 10-molar concentrations of sodium hydroxide along with significant levels of nitrate, nitrite, and other anions render standard ion-exchange, membrane filtration, and other separation technologies relatively ineffective. The EERC corrosives removal system comprises 1) initial chloride and sulfate removal via ion-selective membrane filtration, 2) secondary sulfate removal via sulfate-specific ion exchange with zirconium-, silver-, or other metal-intercalated cation exchange resin, and 3) secondary chloride removal via chloride-specific ion exchange with silver- or other metal-intercalated cation exchange resin. Process systems developed to date have demonstrated $69 \%$ chloride removal (from 15,100 parts per million [ppm] to $4700 \mathrm{ppm}$ ) and $68 \%$ sulfate removal (from 39,200 to $12,600 \mathrm{ppm}$ ) from 10-molar sodium hydroxide solutions. Hanford tank waste chloride and sulfate concentrations can range as high as 15,000 and 40,000 ppm, respectively, and preliminary Duratek-specified target maximum chloride and sulfate concentrations for vitrification feedstocks are 5000 and $2000 \mathrm{ppm}$, respectively. 


\section{EM TASK 20 - PREVENTION OF CHLORIDE CORROSION IN HIGH- TEMPERATURE WASTE TREATMENT SYSTEMS (Corrosives Removal From Vitrification Slurries)}

\section{INTRODUCTION/BACKGROUND}

GTS Duratek is working with BNFL Incorporated on a U.S. Department of Energy (DOE) contract to develop a facility to treat and immobilize radioactive waste at the Hanford site in seutheast Washington. Development of the 10-ton/day Hanford facility will be based on findings from work at Duratek's 3.3-ton/day pilot plant in Columbia, Maryland, which is in the final stage of construction and scheduled for shakedown testing in early 1999. In prior work with the Catholic University of America Vitreous State Laboratory, Duratek has found that slurrying is the most efficient way to introduce low-level radioactive, hazardous, and mixed wastes into vitrification melters. However, many of the Hanford tank wastes to be vitrified contain species (primarily chloride and sulfate) that are corrosive to the vitrifier or the downstream air pollution control equipment, especially under the elevated temperature conditions existent in these components. Removal of these corrosives presents a significant challenge because most tank wastes contain high (up to 10-molar) concentrations of sodium hydroxide $(\mathrm{NaOH})$ along with significant levels of nitrate, nitrite, and other anions, which render standard ion-exchange, membrane filtration, and other separation technologies relatively ineffective (1). In Task 20, the Energy \& Environmental Research Center (EERC) will work with Duratek to develop and optimize a vitrification pretreatment process for consistent, quantitative removal of chloride and sulfate prior to vitrifier injection.

\section{OBJECTIVES}

GTS Duratek will define mixture compositions representative of DOE waste streams requiring vitrification. These defined compositions will encompass typical total dissolved solids loadings based on available data, and will also include recommended surrogates for representing radioactive components. The defined waste slurry simulants will be used in tests to develop and optimize (for scaleup) a pretreatment process enabling consistent removal of chloride and sulfate such that the treated slurries meet Duratek-specified target levels. Preliminary target levels for maximum chloride and sulfate concentrations in vitrification slurries are 5000 and 2000 parts per million (ppm), respectively. Typically encountered Hanford tank waste concentrations for chloride and sulfate range up to 15,000 and $40,000 \mathrm{ppm}$, respectively.

\section{ACCOMPLISHMENTS}

Following a February 1998 meeting in Grand Forks attended by EERC and Duratek "corrosion teams," the EERC developed a corrosives removal pretreatment concept and submitted it to Duratek for review. After several rework and review iterations, the refined 
process concept was approved by Duratek for development. The three-step process comprises 1) initial sulfate and chloride removal via ion-selective membrane separation, 2) secondary sulfate removal via ion exchange using zirconium- or other appropriate metalintercalated cation exchange resin, and 3) secondary chloride removal via ion exchange using silver- or other appropriate metal-intercalated cation exchange resin. A process schematic is provided as Figure 1.

Recent polymer chemistry and manufacturing improvements have led to the development of ion-selective membranes capable of operating at $\mathrm{pH}$ levels of at least 13.5 (2). The EERC received test samples of membranes from Osmonics Desal of Escondido, California, that Osmonics personnel thought would be best suited for sulfate and chloride removal from highly alkaline solutions. Using an EERC-designed test unit (see Figure 2), membranes were evaluated based on separation efficiency and resistance to alkalinity. The membrane evaluation procedure involved filling one test chamber with deionized water and the other chamber with an equal volume of 5-molar sodium hydroxide solution containing about 15,000 and 40,000 ppm chloride and sulfate, respectively, and allowing 4 hours for concentration-driven chloride and sulfate permeation through the ion-selective membrane separating the two chambers. Prior to initiation of testing, a chloride-specific electrode was calibrated for use in tracking chloride concentration throughout the duration of an evaluation. Table 1 shows results for the best-performing membrane. Although the data show only slight concentration-driven chloride and sulfate membrane permeation, better removal efficiencies will likely be achievable with the application of appropriate voltages to promote electrolysis-driven chloride and sulfate membrane permeation (3).

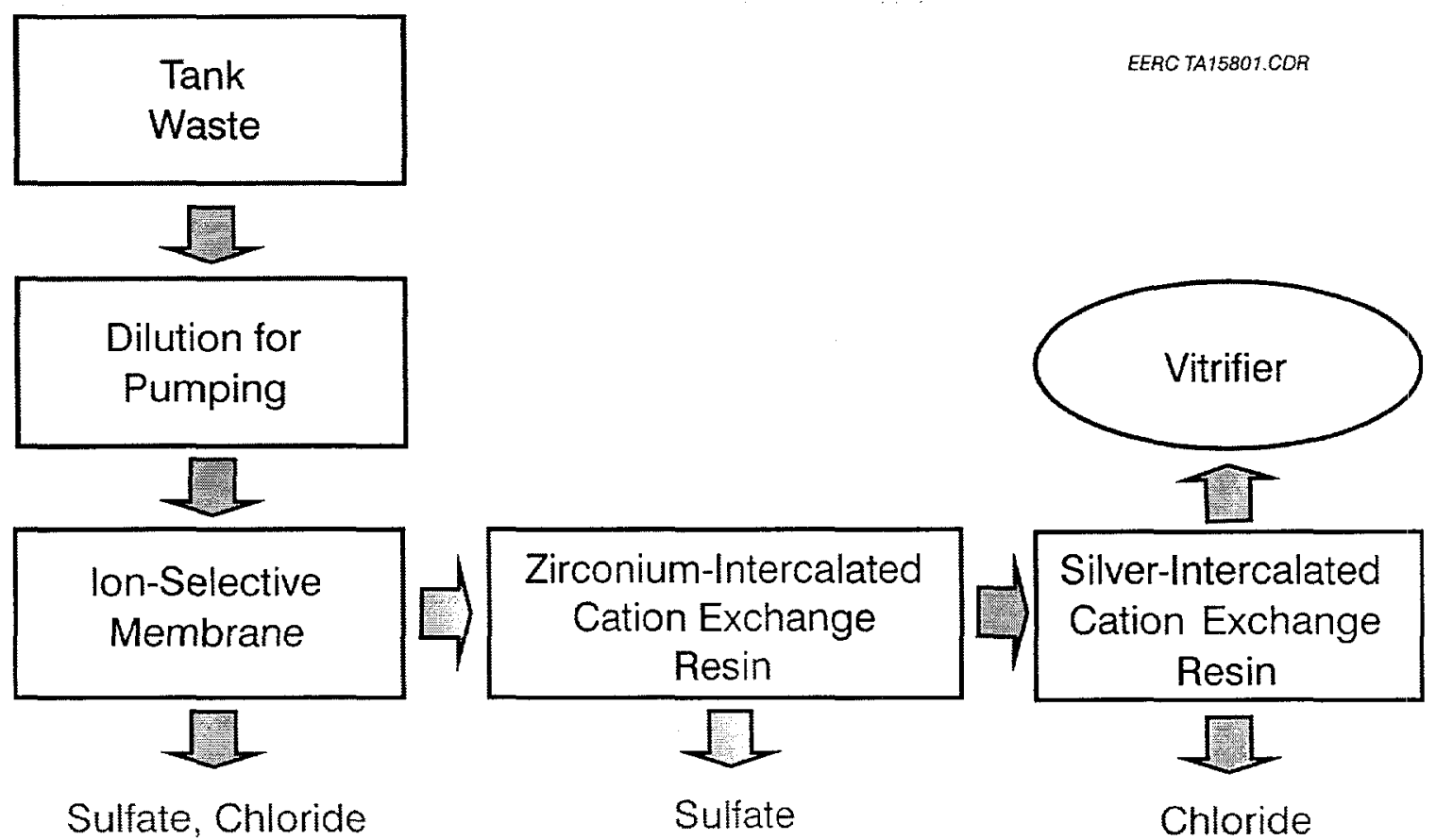

Figure 1. Process configuration. 


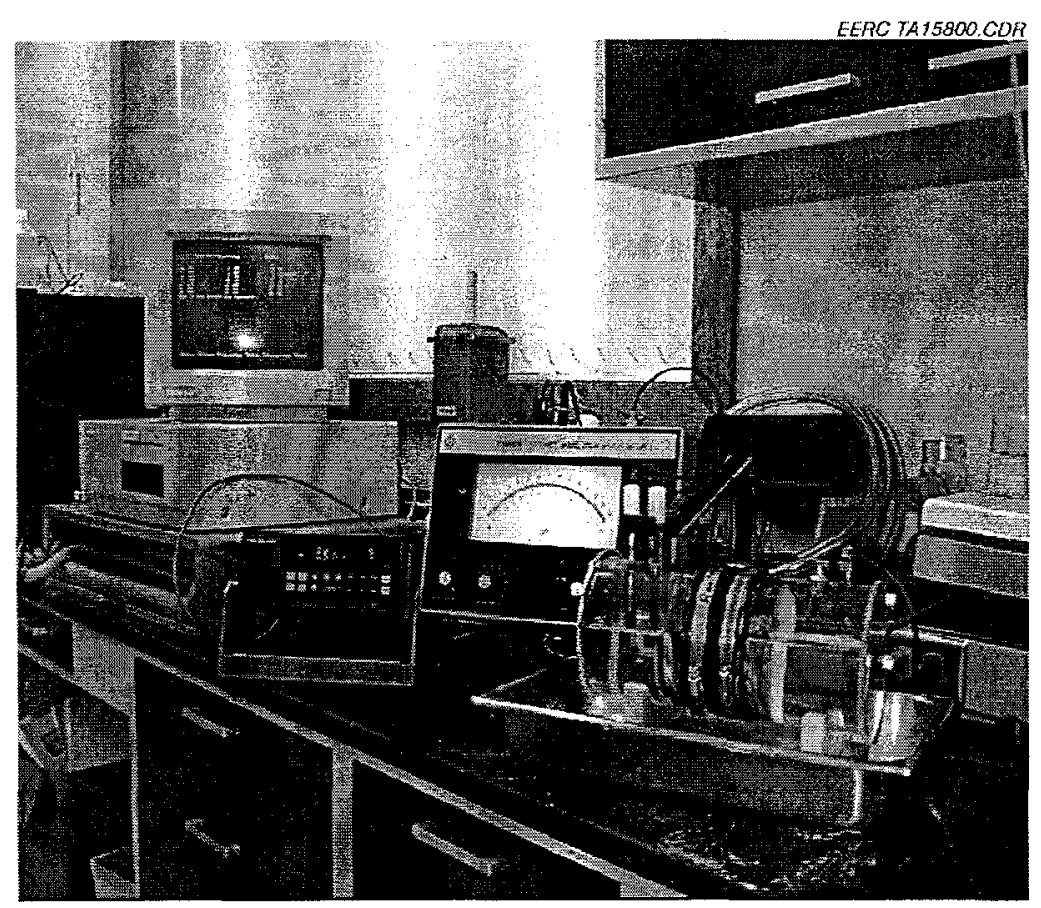

Figure 2. Membrane separation test apparatus.

\section{TABLE 1}

Ion-Specific Membrane Separation - 5-Molar NaOH Solution Diffusion Only - No Electrolysis Voltage

\begin{tabular}{lcccc}
\hline & $\mathrm{Cl}^{-}, \mathrm{ppm}$ & $\begin{array}{c}\mathrm{Cl}^{-} \text {Removal } \\
\text { Efficiency, \% }\end{array}$ & $\mathrm{SO}_{4}^{2-}, \mathrm{ppm}$ & $\begin{array}{c}\mathrm{SO}_{4}^{2-} \text { Removal } \\
\text { Efficiency, \% }\end{array}$ \\
\hline Feed Solution & 15,100 & - & 39,200 & - \\
Membrane Permeate & 1,990 & - & 4,200 & - \\
Treated Solution & 13,110 & 13 & 35,000 & 11 \\
\hline
\end{tabular}

The conversion of a commercial cation exchange resin to an effective anion exchanger involves substituting silver, barium, zirconium, or other appropriate metal for the hydrogen or sodium normally present on the cation exchange resin active sites. This can be accomplished by mixing a weighed amount of commercial cation exchange resin with an equimolar solution of an appropriate metal salt. Several anion exchange resins were prepared for evaluation using Amberlyst 15 cation exchange resin mixed with silver nitrate, barium acetate, barium hydroxide, or calcium hydroxide. Table 2 shows results of tests in which 5-molar $\mathrm{NaOH}$ solutions containing about 5000 and 40,000 ppm chloride and sulfate, respectively, were gravity-fed through a column reactor. The data show that the eluent from the silver-intercalated resin met 
TABLE 2

Ion Exchange via Metal-Intercalated Cation Exchange Resin - 5-Molar NaOH Solution Trickle-Bed Treatment

\begin{tabular}{|c|c|c|c|c|}
\hline & $\mathrm{Cl}^{-}, \mathrm{ppm}$ & $\begin{array}{l}\mathrm{Cl}^{-} \text {Removal } \\
\text { Efficiency, \% }\end{array}$ & $\mathrm{SO}_{4}{ }^{2-}, \mathrm{ppm}$ & $\begin{array}{l}\mathrm{SO}_{4}{ }^{2-} \text { Removal } \\
\text { Efficiency, \% }\end{array}$ \\
\hline Feed Solution & 15,100 & & 39,200 & \\
\hline Silver Resin ${ }^{1}$ Eluent & 4,700 & 69 & 12,600 & 68 \\
\hline Barium Resin ${ }^{2}$ Eluent & 11,400 & 25 & 25,800 & 34 \\
\hline Barium Resin ${ }^{3}$ Eluent & 12,300 & 19 & 30,000 & 23 \\
\hline Calcium Resin ${ }^{4}$ Eluent & 14,400 & 5 & 36,400 & 7 \\
\hline
\end{tabular}

the Duratek-specified chloride target of $5000 \mathrm{ppm}$. Better reductions of both chloride and sulfate concentrations should be achievable with the use of zirconium-intercalated resin and development and optimization of a system incorporating a series of two or more zirconium- and silver-intercalated trickle-bed columns (4-6).

\section{FUTURE WORK}

Upcoming work in the next 2 months will focus on the use of 5-molar $\mathrm{NaOH}$ solutions with 5000- and 40,000-ppm chloride and sulfate concentrations, respectively, to 1) evaluate and select an optimized ion-selective membrane-membrane coating combination to maximize concentration-driven chloride and sulfate membrane permeation, 2) optimize electrolysis methods to maximize total chloride and sulfate membrane permeation, and 3) evaluate and select optimized cation-to-anion exchange resin conversion methods to maximize chloride and sulfate removal via ion exchange. Following completion of simple-solution individual process step optimization, work will commence on integrating the process steps into a total corrosives removal system, optimizing the system using increasingly complex waste simulant mixtures with radionuclide surrogates, and acquiring data for use in setting operational parameters for commercial process development work at the new Duratek pilot plant. 


\section{REFERENCES}

1. Lee, D.D.; Walker, J.F;; Taylor, P.A.; Hendrickson, D.W. Cesium-Removal Flow Studies Using Ion Exchange, Environmental Progress, 1997, Winter.

2. Lien, L. Using Membrane Technology to Minimize Wastewater. Pollution Engineering, 1998, May.

3. Zincus, G.A.; Byers, W.D.; Doerr, W.W. Identify Appropriate Water Reclamation Technologies, Chemical Engineering Progress, 1998, May.

4. U.S. Patent Number 5,618,437. Process for Removing Sulfate from Aqueous Solution.

5. U.S. Patent Number 4,415,677. Removal of Sulfate Ions from Brine Using Composite of Polymeric Zirconium Hydrous Oxide in Macroporous Matrix.

6. U.S. Patent Number 4,415,678. Removal of Sulfate Ions from Brine Using Amorphous Polymeric Zirconium Oxide Formed Within a Macroporous Polymer Matrix. 